This item was submitted to Loughborough's Research Repository by the author.

Items in Figshare are protected by copyright, with all rights reserved, unless otherwise indicated.

\title{
Evaluating the London 2012 Games' impact on sport participation in a non- hosting region: a practical application of realist evaluation
}

PLEASE CITE THE PUBLISHED VERSION

http://dx.doi.org/10.1080/02614367.2015.1040827

\section{PUBLISHER}

(c) Taylor \& Francis

\section{VERSION}

AM (Accepted Manuscript)

\section{PUBLISHER STATEMENT}

This work is made available according to the conditions of the Creative Commons Attribution-NonCommercialNoDerivatives 4.0 International (CC BY-NC-ND 4.0) licence. Full details of this licence are available at: https://creativecommons.org/licenses/by-nc-nd/4.0/

\section{LICENCE}

CC BY-NC-ND 4.0

\section{REPOSITORY RECORD}

Chen, Shushu, and lan Henry. 2015. "Evaluating the London 2012 Games' Impact on Sport Participation in a Non-hosting Region: A Practical Application of Realist Evaluation”. Loughborough University. https://hdl.handle.net/2134/20856. 
Title: Evaluating the London 2012 Games' impact on sport participation in a non-hosting region: a practical application of realist evaluation

\author{
Shushu Chen \\ Ian Henry \\ ${ }^{a}$ Faculty of Arts and Science, Sport and PA Department, Edge Hill \\ University, St Helens Road, Ormskirk, UK; \\ ${ }^{b}$ Centre for Olympic Studies and Research, Loughborough University, \\ Loughborough, LE11 3TU, UK
}

(Submitted 19 May 2014 - accepted for publication 13 January 2015 -accepted version)

Acknowledgement: the authors wish to acknowledge the funding and support for this research project provided by Leicester-Shire \& Rutland Sport and Inspire Leicestershire. Support was initially also provided by emda (the East Midlands Development Agency) before the abolition of RDAs in March 2012.

\begin{abstract}
In the literature on Olympic legacies and impacts there is a dearth of materials that specifically address the issue of Olympic impact for non-hosting regions. The literature tends to deal with impacts at a national level, or at a hosting-city region level, neglecting in large part the degree to which benefits can be leveraged by nonhosting regions. A further limitation identified in the literature is a failure to engage in detailed formal evaluation of policy implementation where assertions of potential policy impact are based on untested assumptions. This study is intended to address both of these concerns. It presents an empirical, 'bottom-up' application of a Realist Evaluation framework to assess the impact of a policy initiative - Workplace Challenge - aimed at leveraging enhanced sports participation in a non-hosting 'region' ${ }^{1}$ - Leicestershire - in the period leading up to the 2012 Games. In doing so it seeks, to identify which causal mechanisms worked within this particular context to produce the observed outcomes. The evaluation results demonstrate that the programme represented a positive approach to fostering regular engagement with sport and physical activities for some groups in some types of organisations; and that awareness and motivational factors associated with the London 2012 Games are, in this case, linked (albeit weakly) to an increase in sport and physical activity participation for specific groups taking part in the programme in particular organisational contexts.
\end{abstract}

Keywords: Realist evaluation, additionality, the London 2012 Games, Olympic impact, sport participation, non-hosting region. 


\section{Introduction}

Although, in recent years we have seen a burgeoning of research studies focusing on the concept of Olympic impact and legacy (see for example, Cashman, 2002; Gold \& Gold, 2009; Gratton \& Preuss, 2008; Malfas, Theodoraki, \& Houlihan, 2004; Toohey, 2008), and on their empirical manifestation (see for example, Andersen, 1999; Blake, 2005; Giannoulakis, Wang, \& Gray, 2008; Gibson, Qi, \& Zhang, 2008; Hughes, 2013; Spilling, 1996; Zhou \& Ap, 2009), such studies have been underdeveloped in a number of ways. In particular, there has been a lack of longitudinal studies of the development of legacy outcomes or impacts (Karadakis \& Kaplanidou, 2012; Tien, Lo, \& Lin, 2011); a lack of empirical post hoc evaluations (Giesecke \& Madden, 2007; Kirkup \& Major, 2006); and a scarcity of studies of impacts in non-hosting regions (see for example, Deccio \& Baloglu, 2002; Ritchie, Shipway, \& Cleeve, 2009; Walton, Longo, \& Dawson, 2008). Much of what has been written about the impacts of the Olympics focuses only on host city and nation (see for example, Baade, Baumann, \& Matheson, 2008; Cashman, 2002; Dansero \& Puttilli, 2010; Guala \& Turco, 2009; Jinxia \& Mangan, 2008; Kapareliotis, Panopoulos, \& Panigyrakis, 2010; Newman, 1999), and consists of cross-sectional analysis which very seldom engage with the perspective(s) of non-hosting regions (Beesley \& Chalip, 2011; Chen, 2013; Kellett, Hede, \& Chalip, 2008; Putsis, 1998) and which by definition have limited potential to identify change across time. In addition such studies, where they are primarily quantitative in nature, have sought to identify statistical associations between dependent outcome variables and independent variables while paying little heed to the heuristic dimension of lessons to be learned concerning the causal mechanisms which bring about such changes.

Further criticisms have suggested that conclusions drawn from legacy and impact studies are inclined towards being overly positive since they tend to be written by stakeholders whose interests lie in promoting the staging of the Games (Crompton, 1995; Lenskyj, 2000, 2002, 2008; Porter \& Fletcher, 2008), and that the complexity of policy contexts renders it difficult to establish empirical evidence of outcomes and the causal mechanisms which bring about such outcomes in project and programme evaluations (Pawson, 2013: see section 2 'The Challenge of Complexity').

The aim of the study reported in this paper is therefore to address some of these issues, undertaking a detailed analysis of a particular local initiative, the Workplace Challenge Programme (WCP) implemented in Leicestershire which aimed to harness increased interest in sport as a by-product of the London 2012 Games in order to increase participation in sport and physical activity within work organisations in the locality. The study seeks to furnish detailed explanation and evaluation of the causal factors at play in generating the outcomes observed in this context, and as such draws upon the main themes of realist evaluation (Pawson, 2013). 


\section{The literature on the impact of hosting the Olympics on participation in sport and physical activity}

There is a considerable literature on the impact of hosting mega-events in general (Fourie \& Santana-Gallego, 2011; Horne, 2007; Kavetsos \& Szymanski, 2010; Kim \& Petrick, 2005), and the Olympics more specifically (Bondonio \& Mela, 2008; Gratton \& Preuss, 2008; Kaplanidou \& Karadakis, 2010; Mangan, 2008; Moreira, 2009). However our focus in this article is on the contribution a particular policy initiative has made to the fostering of participation in sport and physical activity as a product of the staging of the Games in Britain, and we thus focus our attention in the review of material dealing with the impact of the Games on the promotion of sporting and physical recreation and / or physical activity.

The issue of using the Games to leverage increases in healthy, physically active lifestyles is something which has received increasing attention in recent editions of the Games (Haynes, 2001; PriceWaterhouseCoopers \& DCMS, 2005). However, the notion of Olympics inspiring grassroots participation has been challenged in the literature. The direct evidence of sport, health, and physical activity impacts for previous Olympic Games is poor (McCartney et al., 2010; Weed, 2006a): on the one hand, there are some claims of positive evidence (albeit limited in terms of scope and methodological rigour) that suggest that previous Olympics have had a positive impact on participation in physical activity, for example, the case of the Barcelona Games (Truno, 1995) and the Sydney Games (Cashman, 2006). On the other hand, investigations of the same editions of the Games, for example by Murphy and Bauman (2007) conclude that there was no change in the proportion of the population meeting health-enhancing physical activity levels after the 2000 Sydney Games, pointing out that national data indicate that participation rates were even lower in 2000 than in 1999 and 1998. Other studies of the sport participation impact of the Sydney Games resulted in similar findings - suggesting an insignificant change to sport participation levels in general, but with a small short-term increase after the Games (Heuvel, 2001; Veal \& Toohey, 2005) which Veal and Toohey, however, suggest may be attributable to changes in the nature of data collection on the part of governmental bodies.

The results of two systematic literature reviews by McCartney et al (2010) and Weed et al (2008) also address the issue of the health and physical activity impacts of major multi-sport events including the Olympics. Both studies conclude that there is no robust evidence to support the notion that hosting the Olympics has increased sport participation levels for the host nation. However, as the authors of these studies note, at the time of publishing these systematic reviews, there had been no sustained attempt at assessing the participation impact of the Olympics. Indeed Weed et al. (2008: 8) point out, writing prior to the London Games, that not only had there been no sustained evaluation of this effect, but that in fact "the use of an Olympic Games to raise physical activity and sport participation [had] not been attempted in any real sense." Thus, rather than concluding that these studies demonstrate that there is no causal link between hosting of the Olympics and enhanced sport participation it is more accurate to say that the existence of such impact has yet to be demonstrated. In addition one can underline the point that such studies have focused on whether 
there is a significant increase in participation associated with hosting the Games rather than on identifying the assumptions concerning the causal mechanisms implicated in achieving such changes.

As Tew et al. (2012) point out "London 2012 is the first Olympic and Paralympic Games to explicitly try and develop socioeconomic legacies for which success indicators are specified - the highest profile of which was to deliver a health legacy by getting two million more people more active by 2012". The original New Labour government aspirational goal in terms of additional numbers engaging in sport and physical activity across the period was however dropped by the incoming Coalition government in March 2011 as unrealistic (Gibson, 2011). In the period since the Games, with the exception of Grant Thornton, Ecorys, Centre for Olympic Studies \& Research Loughborough University, and Oxford Economics (2013b) there have been relatively few post hoc commentaries in the academic or grey literatures on the sport and physical activity impacts of the Games. Mahtani et al. (2013, p. 1) reviewing and evaluating the quality of the two systematic reviews cited earlier concluded unsurprisingly that there was "a paucity of evidence to support the notion that hosting an Olympic games leads to an increased participation in physical or sporting activities for host countries". Craig and Bauman (2014) report a study employing "objective measures" of the impact of the Vancouver 2010 Games on Canadian children and young people (aged 5-19) and conclude that "The 2010 Olympic Games had no measurable impact on objectively measured physical activity or the prevalence of overall sports participation among Canadian children" (p.1). Other sources employ qualitative data - Piper and Garratt (2013) for example undertake a Foucauldian analysis of the framing of policy, highlighting factors that militated against successful attainments of policy goals in this area, while Feng and Hong (2013) and Reis, de Sousa-Mast, and Gurgel (2014) respectively consider qualitative reports of the impact of the Beijing Games 2008 in Chinese townships, and of the anticipated participation effects among local professionals of the Rio 2016 Games, with both reporting little or no significant impact experienced (in relation to 2008) or anticipated (in relation to 2016).

A unique resource in relation to assessing the impacts of the Olympic Games is the series of reports commissioned by the Department of Culture, Media and Sport from a research consortium led by Grant Thornton Consultants which constitute a metaevaluation of the legacies of the 2012 Olympic and Paralympic Games (Grant Thornton, Ecorys, \& Centre for Olympic Studies \& Research Loughborough University, 2011; Grant Thornton, Ecorys, Centre for Olympic Studies \& Research Loughborough University, \& Oxford Economics, 2011, 2012a, 2012b; Grant Thornton et al., 2013b). The two primary concerns of a meta-evaluation are with 'metasynthesis', the aggregating of data and / or lessons learned from individual studies to form more robust, evidenced-based conclusions in respect of the phenomena under evaluation; and with the 'evaluation of the evaluations', which seeks to assess the quality and rigour of the methods employed and thus assess the level of confidence that can be expressed in the results obtained by the individual studies and thus by their synthesis (Chen, Henry, \& Ko, 2013). The approach adopted by the authors in relation to the metaevaluation exercise was to structure each of its five reports along the lines of government legacy goals and within this context a single chapter in 
each of the reports was dedicated to the assessment of sporting legacy including sporting participation impacts.

A problem experienced by the members of the consortium dealing with the metaevaluation of sporting legacies (and thus with evaluating the impact of hosting the games on sport and exercise participation) was that there appeared to be anomalies discovered in synthesizing the lessons learned on the one hand from the national participation surveys Taking Part (Jones, Millward, \& Buraimo, 2011) and Active People (Sport England, 2011) with those learned from the studies of individual projects / programmes aimed at increasing participation largely at the local level (the metaevaluation study focused on 20 of the most significant of such projects, including for example Sportivate, Gold Challenge, Free Swimming, and Premier League for Sport, Grant Thornton, ECORYS, Centre for Olympic Studies \& Research Loughborough University, \& Oxford Economics, 2013a). While the data from the national surveys in the run up to 2012 indicated that there had generally been no significant increase in participation (until the year of the Games itself), data from the individual projects implemented at local level pointed towards increased participation across the whole period from 2007. One explanation of these apparently incompatible findings was that local level analysis for the most part failed to consider aspects of additionality. In effect, for many of the projects, the gross impact rather than the net impact of such projects was reported with the evaluations of these projects failing to take account of the four key factors to be considered in calculating additionality, namely leakage, substitution, displacement, and the multiplier effects.

An exception to this was an evaluation study of the impact of the Free Swimming Programme, "a $£ 140$ million programme designed to increase participation in swimming in England and lead to subsequent health and economic benefits ... based around local authorities providing free swimming for children aged 16 or under and for adults aged 60 or over" (DCMS, 2010: 1). The publication by PricewaterhouseCoopers of the evaluation report commissioned by the DCMS led to the early termination of this programme, in part because, despite an increasing number of swims being recorded, the estimation of additionality highlighted the fact that new swimmers (particularly among the older population) were not being attracted in large numbers, but that existing swimmers were simply attending more frequently (thus a form of leakage was taking place), and participants were also reporting aspects of substitution of free swimming for other forms of exercise (PricewaterhouseCoopers, 2010).

The identification of a lack of measures to assess additionality is a good illustration of the product of 'evaluation of evaluations' in which one can point to shortcomings in methods employed that militate against the ability to synthesise the data and lessons from these two types of data source, national surveys and projects and programmes aimed at stimulating participation in sport and exercise. 


\section{Leveraging impact from the London 2012 Games in a non-hosting region and sub-region: the East Midlands and Leicestershire}

The London 2012 Olympic and Paralympic Games were the biggest sporting events in UK history. London 2012-related events were delivered largely in London but also in a number of other venues (in the cases for example of sailing or football) and although government emphasised the concept of a 'UK Games' hosted in London, from the outset commentators noted the disproportionate benefit to London's economy and the potential negative impacts on other regions (Blake, 2005). However there appears to have been little subsequent systematic focus on the impact of the Games in non-hosting regions, as illustrated by Bloyce and Lovett's (2012) analysis of legacy discourses in Olympic related documents. In this study 102 documents were sourced from government departments and Olympic bodies (and subsequent snowball sampling), but none of the studies reviewed focused on regional leverage of benefits by non-hosting regions. Regional strategies were set out by many regions with varying degrees of detail and of resource provided, but this has attracted little coverage in the published academic literature (see for example, Gilmore, 2014).

Local stakeholders in Leicestershire led by the East Midlands Development Agency (emda), Leicester and Leicestershire local authorities, produced one of the more developed local / regional strategies to leverage benefits from the Games, establishing the Leicestershire Steering Group for the 2012 Games to develop and oversee strategy in this area. This temporary body established in 2009 published its strategy statement through Inspire Leicestershire which was set up as the public face of the Steering Group (Inspire Leicestershire, 2009). The strategy was developed around seven core themes: business, visitor economy, sport and physical activity, culture, children and young people, health and wellbeing, and volunteering. Each with a named lead organisation and with its actions coordinated through a delivery group, normally an existing group or partnership currently working within that theme area (see Figure 1). 
Figure 1: The Context of the Regional Strategy for Leveraging Benefits from the London 2012 Olympic and Paralympic Games in Leicestershire.

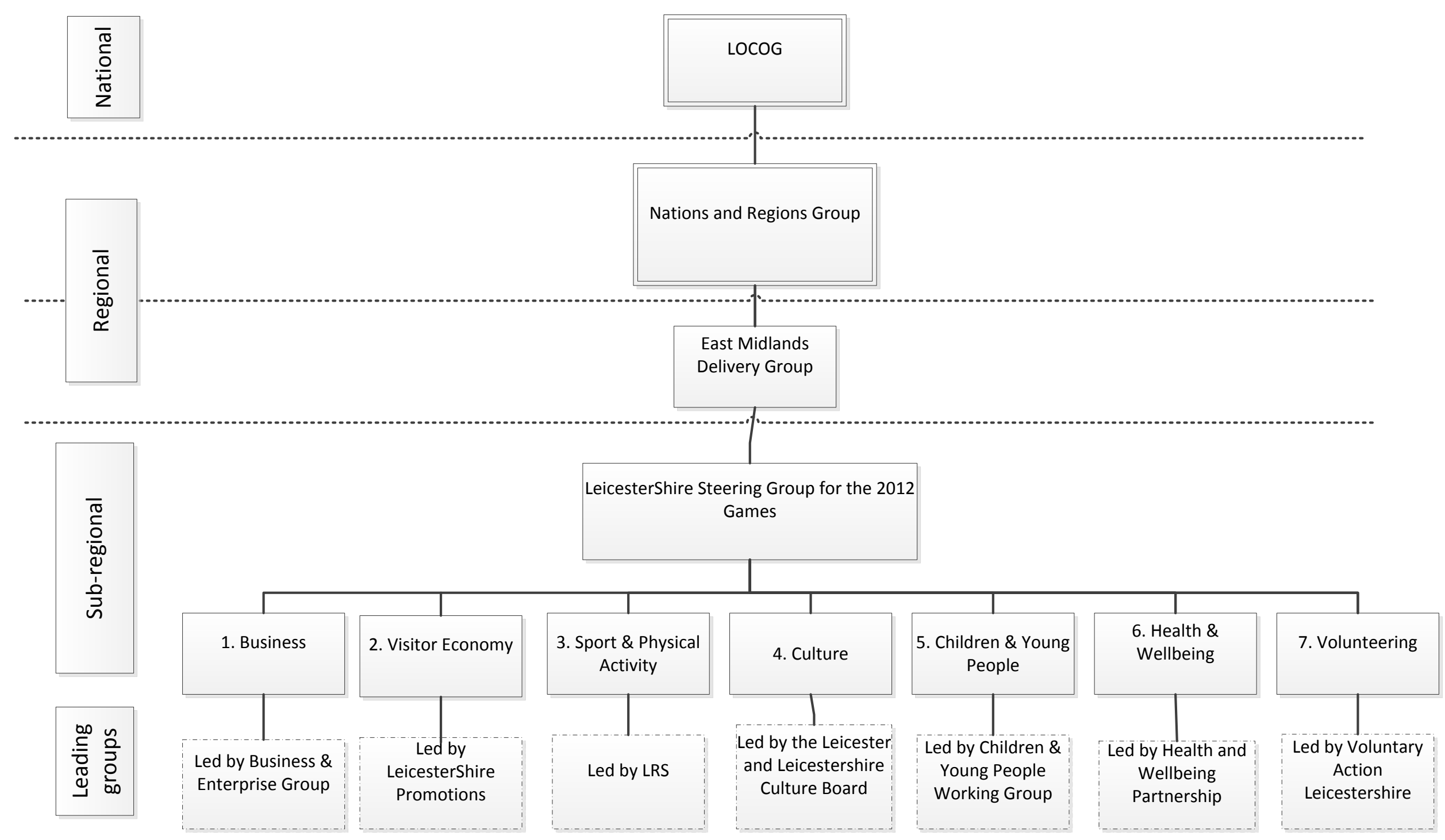


The County Sport Partnership, Leicester-Shire \& Rutland Sport (LRS), was the agency responsible for leading the sport strand in the sub-region. The key priorities under the sport strand were focused on increasing community participation and supporting talented athletes. This was to be promoted through delivering nationally initiated legacy programmes and regionally developed, sport-related programmes (including the Workplace Challenge Programme), new investments in infrastructure, and allocating sports funds for athletes.

In evaluating national level data relating to participation one is dealing predominantly with descriptive (statistical) accounts of the changing nature of sports participation nationally. Local programmes however may be more amenable to qualitative and / quantitative evidence to support causal accounts of how behaviour change is actually brought about. Our primary concern therefore in the empirical element of this paper is to take one local programme, the Workplace Challenge Programme (WCP), as an example of a programme aimed at increasing participation in sport and exercise, and to explore the context within which that programme operated, the assumptions made by some stakeholders in relation to how interventions could result in generating higher levels of sport and exercise in workplace organisations, the evidence of relationship between the causal mechanisms assumed to operate in this case, and the nature of outcomes achieved. WCP was a free, online competition between businesses that allowed participants to log their activity over the course of the programme. Prizes were offered to encourage continued participation in WCP by individuals as well as the overall workplace, with prizes totalling $£ 4,000$ (e.g. prizes of $£ 2000$ for the most active organisation, a bike for the most active participant). The aim of the WCP was to stimulate competition between organisations in terms of the recorded levels of sport and exercise undertaken by their employees over a given period. There were many toolkits, resources and forms of support available, with information to help the workplace organisation to actively engage with the programme (e.g. providing organisations with promotional materials such as Workplace Challenge Posters, Powerpoint presentations, and leaflets, and information about quick and easy ways to gain points and get employers involved). Although WCP was initially planned to run in 2011 only, after successful outcomes in year one, and with the anticipation that the 'London 2012 effect' might further boost the number of participants in the programme in 'Olympic year', LRS decided to use some surplus funding to repeat the programme in 2012 (Year 1: Jan - July 2011; Year 2: March - July 2012). The programme was funded by Leicestershire County Council, Leicestershire Together, Leicestershire County and Rutland NHS, seven District Councils, and Corporate Games.

From the outset of the strategy and its various projects the Leicestershire Steering Group members (and especially LRS) recognised a need to evaluate as much of the programme as possible and thus commissioned a three-year study on the part of the Centre for Olympic Studies and Research in 2010. The research brief was to evaluate the level of success of selected projects which after consultation was interpreted as identifying what works for whom in what circumstances - in other words to identify the 'generative mechanisms' in order to be able to recognise and explain the nature 
of, and reasons for, success / failings of the programme, and thus implications for policy.

In order to assess the WCP's contribution towards promoting sport and physical activity participation, and to explore the possible impact the 2012 Games may have on the promotion and staging of the WCP. The following research questions were developed as the point for departure for the study:

- $\quad$ To what extent did the WCP contribute to any increase in sport and physical activity participation amongst staff in participating organisations in Leicestershire?

- In what ways did the promotion and staging of the WCP achieve these outcomes (what were the causal mechanisms involved)?

- What are the factors that mediated the level of success, or were barriers to success and why?

\section{Methodology}

The approach adopted in this study in ontological terms is related to the Realist Evaluation approach of Pawson and his colleagues (Pawson, 2001; Pawson, 2006; Pawson, 2013; Pawson \& Tilley, 2004). While Pawson and Tilley's approach (and their initial use of the term Scientific Realism) denotes a deviation from other forms of realist social analysis (most notably the critical realism of Roy Bhaskar, 1998) it places emphasis on context-specific explanations of generative mechanisms. Explanations which employ realist evaluation are thus focused on defining how outcomes are brought about by generative mechanisms or causal processes operating in specific contexts. Pawson and Tilley (1997) propose a basic realist explanatory formula that context (C) plus mechanism (M) equals outcome (O). They refer to this formulation as a $\mathrm{CMO}$ configuration which summarises their explanatory framework.

Essentially, the CMO configuration is a useful conceptual framework when trying to tease out how and in what circumstances a programme might work, and why and in what circumstances it might not work. Mechanisms are embedded in programmes and interventions that bring about effects which may be intended or unintended. 'Mechanisms' thus refers to the resources that programmes or projects offer to enable their subjects to make them work and thus they form part of the logic of an intervention, which constitutes the key features of programme theory. 'Context' denotes the conditions under which programmes are introduced that are relevant to the operation of the programme mechanisms. The context can relate to material conditions but also to systems of interpersonal and social relationships, to technology and economic conditions. 'Outcome-patterns' describe the intended and unintended consequences of programmes, as results of the activation of different mechanisms in different contexts (see discussion of $\mathrm{CMO}_{1}$ and $\mathrm{CMO}_{2}$ later in this paper).

The realist approach places emphasis on beginning evaluation with programme theory. In our case the theory is represented in the assumptions of the designers of 
the WCP, as evidenced in the responses of interviewees responsible for planning and delivery of the programme, and in the WCP documentation. The programme theory for this intervention is discussed below.

While in methodological terms realist evaluation requires specific types of ontologically defined explanation, it is relatively method-neutral, accommodating and indeed requiring in many circumstances a mix of quantitative and qualitative methods, with quantitative methods tending to focus on context and outcomes, while qualitative methods tend to be used to probe explanations of causal or generative mechanisms. The research design for this study used mixed methods, quantitative and qualitative approaches.

All the WCP participants, who provided their email addresses when they signed up to the programme, were contacted by email with a message to explain the purpose of the research, together with the web link of a questionnaire. The initial distribution of self-administered questionnaires was seen as appropriate for this study to discover a broad range of information about the programme participants, including for example, age, gender, previous and current participation level of sport and physical activity, personal interest in London 2012 and the Games' potential impacts. Based on the feedback collected from the survey, semi-structured interviews were then applied to further explore the identified causal links (in particular, to identify the ways in which the London 2012 Games had impacted on influencing participation in the programme). In total, two sets of survey data and one set of semi-structured interviews were collected in two stages, after the completion of each year's operation of the WCP.

\section{Stage 1 data collection (August-September 2011)}

- An initial questionnaire survey of the nature and rate of, and the rationales for, participation in sport and physical activity of those taking part in the programme was staged at the end of the 2011 edition of the WCP. From the questionnaires made available by email to the 827 people from 67 workplaces taking part in the 2011 WCP, 15\% returned usable completed questionnaires (a small but usable response rate in the context of our aims, $n$ $=125$, thus with a $95 \%$ confidence level, giving a modest confidence interval of up to $\pm 8 \%$ ). The survey questions explored the extent to which the programme contributed to increased sport and physical activity participation amongst staff in participating organisations in Leicestershire; and the extent to which the fact of the 2012 Games being hosted in London had boosted interest and the level of outputs achieved.

- Interviews with internal stakeholders: A small number of interviews were undertaken with individuals from two groups of internal stakeholders. The first was with the two officers from LRS responsible for operating the programme. These sought to identify what, if any, additional policy and promotional support had been provided by virtue of the staging of the 2012 Games in London. Given that preliminary quantitative results indicated that the London Games had motivated participants to undertake more physical activity, another interview group representing a total of six internal 
stakeholders, one each from six participating organisations, was selected to tease out the interviewees' perceptions of the nature of, and of the mechanisms for, the additional impacts that the London Games had generated in their particular organisation.

Stage 2 data collection (August-September 2012):

- A second survey of the nature and rates of, and the rationales for, participating in sport and physical activity of those taking part in the WCP was implemented via another round of questionnaires distributed by email immediately after the 2012 WCP finished. Within the 1176 participants taking part in the 2012 WCP, 7\% returned completed questionnaires survey ( $n=77$, thus with a $95 \%$ confidence level, the confidence interval is $\pm 10 \%)$. A majority of the survey questions remained the same as had been used in the questionnaire employed the previous year, with a small number of additional questions. These sought to identify, for example, whether the participants had been involved with the programme during the previous year; if so, had there been any change in the frequency/intensity of participation; the level of awareness of physical activity-related knowledge (e.g. concerning the national recommended physical activity levels for adults); and a preprogramme question on 'how many days per week on average were you taking part in moderate intensity physical activity for at least 30 minutes prior to the WCP?'.

\section{Results}

(a) Programme Theory Underpinning the Workplace Challenge Programme

The aim of the WCP was to foster the adoption of more active lifestyles within Leicestershire's work organisations. The realist approach places emphasis on beginning evaluation with programme theory or theory of change, normally a form of middle-range theory, that makes explicit the mechanisms to be employed and their causal relationship to intended outcomes. In our case the theory is represented in the assumptions of the designers of the WCP. As a first step in the process of realist evaluation we sought to identify the assumptions underlying the approach adopted in the use of the WCP to increase participation in sport and physical activity. Following interviews with staff of the LRS responsible for designing and implementing the WCP, and analysis of the accompanying documentation for the programme, we identified the following underlying premises, or chain of logic which represents the basis of the programme theory in this context (see Table 1). 
Table 1: Summary of the chain of logic constituting the WCP 'programme theory'

1. The publicity accorded to the staging of the Olympics in the UK provides a focus for publicity concerning sport.

2. The affective impact (for many people) of the prospect of the proximity of this megaevent generates greater interest in, and a positive response to, sport-related lifestyles for a significant proportion of the population.

3. The Leicestershire Steering Group / Inspire Leicestershire provided information on the benefits of exercise, the required levels of participation and intensity required to generate health benefits, as well as information on how participation in sport and activity in the workplace, or among the workforce, can be increased.

4. The incentive to participate in sport and physical activity will be strengthened, and tendencies for recidivism will be undermined, if records of progress are kept and performance, in terms of maintaining increased levels of participation, rewarded.

5. The provision of opportunities for sport (in intra- and inter-organisational competitions) will provide opportunities for social contexts (e.g. teamwork promoting social bonding), which have the potential to make exercise and the context of exercise more enjoyable.

6. Competition between organisations in terms of levels of exercise undertaken by the workforce, and measurement and recording of exercise levels, will motivate employees to sustain and improve their performance.

7. The increase in physical activity that is thus promoted will enhance the physical health of those members of the workforce who participate, and thus will reduce public health costs.

\section{(b) Reported Level of Impact on Participation in Sport and Physical activity}

In general, since taking part in WCP, around half of the respondents either agreed or strongly agreed that they had increased the overall amount of physical activity they undertook. This was reported in both of the surveys in 2011 and 2012. In particular, $50 \%$ of the 2011 survey respondents indicated that the WCP itself had motivated them to do more in sport and leisure activities. This figure slightly increased (by 1\%) in the 2012 survey. In addition, 40\% of the 2011 respondents and 39\% of the 2012 respondents either agreed or strongly agreed that they had participated in new sport and leisure activities since participating in the WCP

A paired-samples t-test was conducted to evaluate the impact of the 2012 WCP on the level of physical activity participation from Time 1 (prior to the 2012 WCP participation) to Time 2 (after taking part in the 2012 WCP) (see Figure 2). There was a statistically significant increase in the self-reported level of physical activity participation: the mean increase was 1.33 days with at least 30 minutes of moderate intensity physical activity ${ }^{2}$. 
An independent samples t-test was run for the three reflecting self-reported increases in participation in sport and physical activity by gender and age variables ${ }^{3}$. For all three variables there were no significant differences in the scores between males and females, nor between age groups.

For one variable where there was a significant increase in participation pre-and post2012 i.e. "Self-reported increase in number of time units of active participation". Two paired sample t-tests, one for women and one for men, to investigate increase from Time 1 (before the Games) to Time 2 (2012, immediately after the Games). There were significant increases in participation for both men (the mean increase was 1.87 days with at least 30 minutes of moderate intensity physical activity) and women (the mean increase was 1 day) ${ }^{4}$.

As further explored in the interviews, general feedback from the six interviewees from organisations taking part in the programme indicated that being attracted and hence taking part in the WCP was, for some at least, a product of features of the design of the programme as competitive and motivational.

'I think, it is...it (WCP) can be quite motivational, it could be competitive. Particularly, when involving the 'activity log' section of it.'

--- Interview:20.01.2012

'It was a motivator! And it also gave me a chance to raise a little bit money [from sponsorship] as well. From 6 to 8 weeks period of that, I actually raised about $£ 400$, or something, by cycling to work, nearly 30miles every day. 1 think the programme is a really positive thing. And, I've also signed up for 2012 WCP.'

--- Interview:24.01.2012

Figure 2 Comparison of the days of moderate intensity physical activity (at least 30 minutes) per week before and after the 2012 Challenge programme

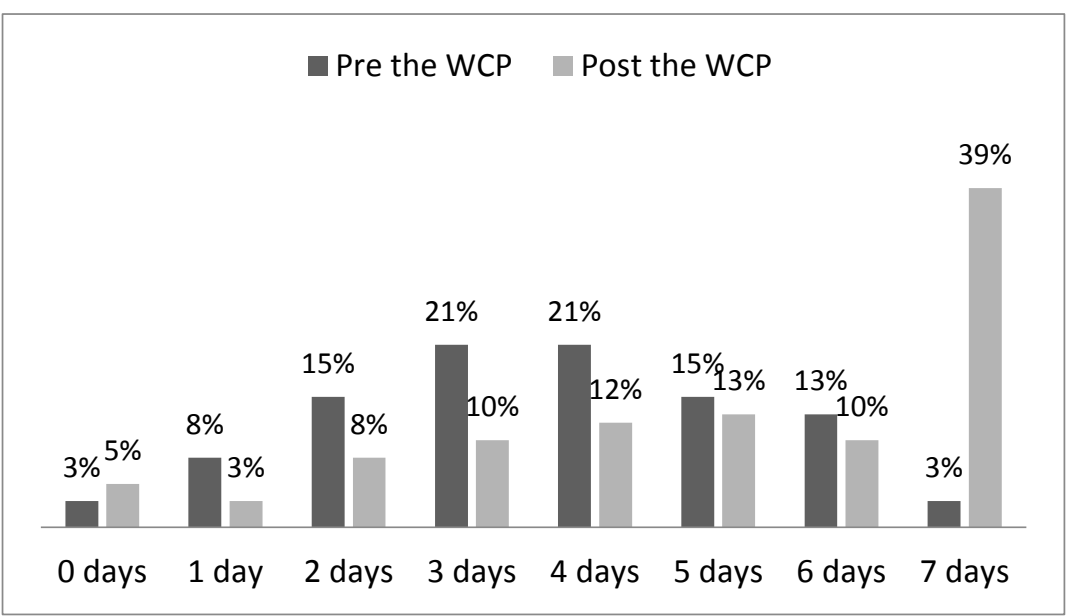


In order to assess the London 2012 impact, in terms of whether the fact of the 2012 Games taking place in Britain had boosted interest and outputs, a series of London 2012 related questions were included in the survey. This generated a number of interesting responses. First, both surveys reported a majority of the respondents indicating their general enthusiasm for the Games: around $76 \%$ of the respondents reported that they either strongly agreed, or agreed, that 'they are interested in the London 2012 Games'. Secondly, around 30\% of the respondents suggested that the London Games had increased their awareness of the benefits of taking part in sport and physical activity. Thirdly, in terms of the motivational impact of the Games, people's perception of the most likely sporting impacts of the London 2012 Games for them were as follows, 33\% of respondents reported themselves 'to be more interested in sport', $31 \%$ 'to be more active', and $25 \%$ to be willing 'to try a new sport/activity'.

With the purpose of assessing whether any two variables are associated (e.g. whether the influence of the Games, for example, in raising people's awareness of the benefits of taking part in sport and physical activity, would be associated with a change in behaviour, in terms of participating more in sport and physical activity), Pearson correlation tests were undertaken: with three positive (one small and two moderate) correlations between the staging of the London 2012 and self-reported behavioural change being identified ${ }^{5}$. From the results it can be inferred that, the motivational factor of the staging of the Games is linked (albeit weakly) to reported increases in sport and physical activity participation and/or participation in new sports and leisure activity through taking part in the WCP. In other words, the London 2012 Games was associated with raised awareness of the benefits of taking part in sport and physical activity, and with increased motivation on the part of some WCP participants to play more sport and physical activity and/or to take part in new sports.

As indicated earlier, the process of identifying the additional impact generated from the UK hosting the Games requires some acknowledgement of, and, where possible, operationalising of four key concepts (i.e. leakage, displacement, substitution, multiplier effect) in the observed outcomes. Table 2 is a tentative exercise in identifying the ways these four elements might affect the net impact of the WCP. The quantification of these elements is difficult, though in the case of participation levels this is mediated by the fact that the questions employed required respondents to give an assessment of net increase in participation, in effect allowing us to discount aspects of substitution. In addition interviews with the key stakeholders facilitated the discovery of displacement where new activities in the WCP were displacing other forms of provision. Nonetheless, the following table is an attempt to draw these various threads together for this case. 
Table 2 Defining the four key additionality related concepts in the case of WCP

\begin{tabular}{|c|c|c|}
\hline Concepts & WCP & Finding \\
\hline Leakage & $\begin{array}{l}\text { i) Since the WCP was aimed at ensuring Leicestershire residents } \\
\text { were more active, beneficiaries of the WCP who live outside of } \\
\text { Leicestershire and benefit from the programme would constitute } \\
\text { leakage. } \\
\text { (ii) Since the programme was intended to target 'less active' adults } \\
\text { in the workplace to become active, there is a possibility that in fact a } \\
\text { large number of 'active' adults benefited from the programme, } \\
\text { constituting a second form of 'leakage. }\end{array}$ & $\begin{array}{l}\text { i) The first form of leakage proved to be negligible. WCP demographics indicated that majority } \\
\text { of participants reside in Leicestershire. } \\
\text { (ii) There was a leakage in the programme in the sense that, as identified in the interviews, } \\
\text { majority impact was reported by a group of people who were already active and were not } \\
\text { therefore the intended target (or at least not the primary intended target) of the intervention. }\end{array}$ \\
\hline Displacement & $\begin{array}{l}\text { Refers to the case which the WCP displaces existing programme(s) } \\
\text { of sport or physical activity provided for example by the employer. }\end{array}$ & $\begin{array}{l}\text { Interestingly, it was evident from the qualitative data that some of the workplaces were } \\
\text { designing a similar initiative within their organisations, or had already been running their own } \\
\text { workplace challenge programme. While WCP was taking place, they either linked the two } \\
\text { programmes together or stopped their own programme and took part in WCP (the latter action } \\
\text { constituting a form of displacement). Where such displacement took place qualitative } \\
\text { interviews indicated that this was largely because WCP was perceived as better organised, and } \\
\text { initiatives. Such as the mini-leagues between different organisations were regarded as more } \\
\text { enjoyable. In this respect, displacement did exist and this is a cost which, though not quantified, } \\
\text { nevertheless should be borne in mind when summarising the final impacts of the programme. }\end{array}$ \\
\hline Substitution & $\begin{array}{l}\text { Refers to the situation in which, as a consequence of taking part in } \\
\text { the sporting or physical activity competitions provided by WCP, } \\
\text { participants ceased to participate in other sporting or fitness } \\
\text { activities. In such cases they would have substituted WCP activities } \\
\text { for others. }\end{array}$ & $\begin{array}{l}\text { The questionnaire asked respondents to specify whether they had experienced a net increase } \\
\text { in participation, in other words such a measure would allow for overall participation data to be } \\
\text { calculated while making allowance for forms of substitution. }\end{array}$ \\
\hline Multiplier effects & $\begin{array}{l}\text { Refers to, for example, after recognising and experiencing those } \\
\text { physical related or mental related benefits as a result of regularly } \\
\text { taking part in sport and physical activity via WCP, the participants } \\
\text { may start to encourage their friends and family to join the scheme } \\
\text { or doing exercise on their own. }\end{array}$ & The multiplier effect was not captured in this case. \\
\hline
\end{tabular}


(d) Evaluation of the Programme Theory underpinning the WCP: impacts on relatively inactive, relatively active members of the workforce.

This section summarises the outcomes achieved in the programme, linking what was achieved in each area with the inputs and mechanisms evidenced, in order to draw out what worked, for whom, in what circumstances. In this way, as Pawson and Tilley (1997) have suggested, there is more potential for generalising lessons from this case study, when seeking to identify such mechanisms in similar contexts might be attempted.

The following tables summarise findings from WCP using two matrices of ContextMechanism-Outcome (CMO) configurations to capture the unique characteristics of each implementation. Two CMO configurations draw together the key insights gained across the internal stakeholder interviews and analysis of the survey data in relation to the implementation of the programme in different contexts. The first configuration $\left(\mathrm{CMO}_{1}\right)$ describes the reception and reaction to the WCP among three groups differentiated in terms of their self-reported level of participation in sport and physical activity at the start of the WCP.

The hypothesis outlined in $\mathrm{CMO}_{1}$ (see Table 3 ) was that participants with different exercise intensity levels at the start of the programme (i.e. Type 1 - people who were new to sport prior to the staging of the WCP, Type $\mathbf{2}$ - people who have participated in sport and physical activity but relatively less often (1-3) prior to the staging of the WCP, Type 3 - People who have regularly participated in sport and physical activity prior to the staging of the WCP) might react differently to mechanisms thus generating different outcomes.

For the Type 1 participants, before the launch of the WCP, it was presumed that people who were inactive and perhaps had a sedentary work role, might have their awareness raised in relation to the health benefits of sport and physical activity in the promotion of health awareness and the benefits of exercise in the context of London 2012, and thus might be motivated to participate in this programme and ancillary sport and physical activity. The data suggest that, firstly, a majority of the Type 1 participants lacked an awareness of the physical activity level recommended for adults by health professionals and national bodies. According to Weinstein (1988), whether a person intends to change his/her behaviour depends on the extent to which a person perceives their own behaviours as 'unhealthy'. In other words, a lack of awareness of the recommended 'healthy' level of physical activity participation may have an impact on whether there would be a behaviour change in terms of participation following an intervention. This may go some way perhaps to explain their less active lifestyle since they may have assumed themselves to be 'sufficiently active' already. Secondly, despite limitations in facilities in the workplace (e.g. lack of showers), this type of participant acknowledged that the London 2012 Games had raised their awareness of the benefits of taking part in sport and physical activity. Members of this group also reported that they had already initiated participation in 
some new (to them) sport and physical activity through taking part in WCP, e.g. via the Cycle/Active Travel Challenge scheme.

Among a range of incentives provided by the programme to motivate participants to do more sport in the future, the provision of vouchers (i.e. $£ 10$ sports shop vouchers) was cited by respondents as the option most likely to be effective in encouraging additional participation. In other words the extrinsic motivators (earning vouchers) were perceived as providing a more effective mechanisms for the Type 2 group. In terms of outcomes, a willingness to participate regularly in sport and physical activity in the future was reported in the survey by this type of participant. In addition, other social impacts / benefits, e.g. increasing confidence in the workplace, greater social interaction were also suggested.

Regarding the characteristics of the Type 2 participants, a preference for doing sport and physical activity as an individual was identified. The log section provided by WCP was considered as a motivational tool encouraging them to take part in more sport and physical activity. Some members of this group reported themselves to have been motivated by this aspect, and an increase of sport and physical activity participation was reported.

Various sporting competitions and the mini-league competitions offered by the WCP proved to be effective in attracting the Type 3 participants, which may reflect the fact that as already committed participants in sport the competitive environment was something which appealed to them. Although it was acknowledged by some Type 3 participants that due to time constraints, they had experienced difficulties in increasing their total number of hours of sport and physical activity participation, many still indicated that the WCP offered different types of sport and physical activity for them to try, and helped them to sustain existing participation levels. 
Table $3 \mathrm{CMO}_{1}$ for the WCP in terms of different intensity level of sports and physical activities participation

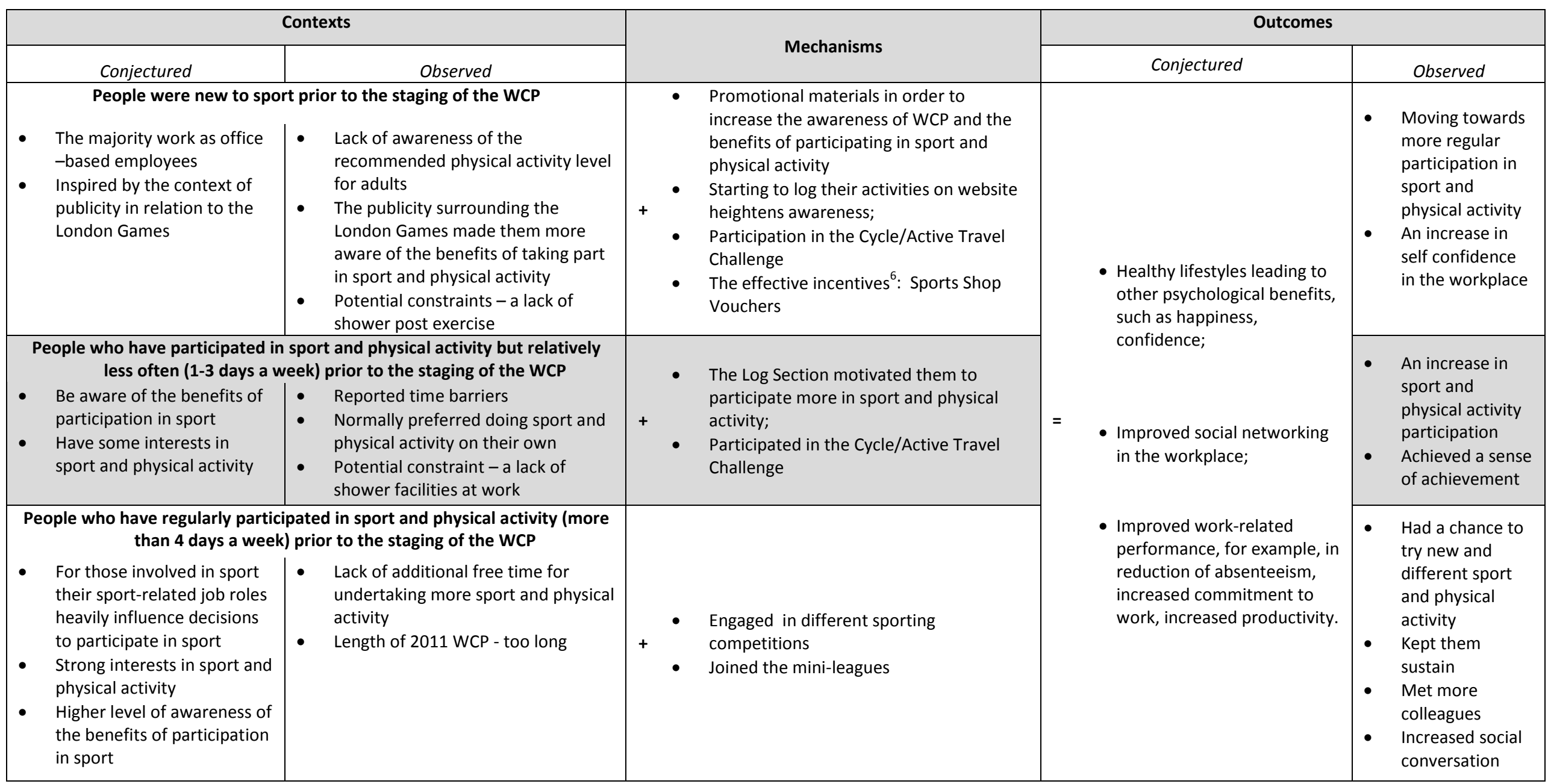


(e) Evaluation of the Programme Theory underpinning the WCP: impacts in different types of work organisation.

It was also one of LRS's intentions, through evaluating WCP, to identify the different mechanisms which were at play in different types of Leicestershire workplaces took part in the WCP. The sources from which the WCP participants came were quite different in relation to the various types of organisation (i.e. local authorities, educational institutions, Public sector/Sport Organisations, and Private sector/Others).

In terms of differences in context, features of these four types of organisations are summarised in the $\mathrm{CMO}_{2}$ configuration (see Table 4). For example, it was evident from the quantitative and qualitative data that, as participants from Educational Institutions were more likely to be aware of the benefits of taking part in sport and physical activity, there may be a greater predisposition to have attention and interest drawn by a sport and physical activity programme (such as WCP). In addition, their comparatively flexible working hours and convenient facilities made participation simpler. In relation to local authority organisations, since LRS maintained a close working relationship with a number of local authorities on a daily basis, the opportunit to promote WCP within them was greater than that for other types of bodies, which may explain a relatively higher number of participants signing up from Local authorities in the programme.

In terms of mechanisms, different marketing strategies may have different appeal to different types of organisations. While the two most effective communication channels identified for promoting WCP for all four types of organisations were emails/newsletter and one-to-one direct 'selling' by LRS team, a large number of workplaces from Local Authorities and Public Sector/Sport Organisations were recruited into the programme because of their previous involvement in other sports programmes provided by LRS; in particular, for the Private Sector/Other Participating Organisations, LRS proposed attending a meeting in the workplace to discuss the programme which may have established a better understanding of what WCP offered and thus a greater willingness to take part. To further identify what kinds of incentives may increase participation in future programme, the $\mathrm{CMO}_{2}$ configuration summarises the slightly different preferences for the four types of organisations respectively (see Table 4). 
Table $4 \mathrm{CMO}_{2}$ for the WCP in terms of different categories of participated organisations

\begin{tabular}{|c|c|c|}
\hline Contexts & Mechanisms & Outcomes \\
\hline $\begin{array}{l}\text { Local Authorities } \\
\text { - Worked closely with LRS on a daily basis; }\end{array}$ & $\begin{array}{l}\text { Promoting WCP by the following three main communication } \\
\text { channels: } \\
\text { - } \quad \text { LRS team; } \\
\text { - } \quad \text { Active Together Partners; } \\
\text { - Emails / newsletter } \\
+\quad \text { Regular visiting of the WCP website (Once or twice a week); } \\
\text { - The effective incentives: } \\
\text { - Sports shop vouchers } \\
-\quad \text { Tickets to events/matches } \\
\text { - Sports equipment } \\
\text { - Strong management support by own organisation was viewed } \\
\text { as critical }\end{array}$ & $\begin{array}{l}\text { - Over half of the respondents reported that the level of sports and physical } \\
\text { activity participation had increased since taking part in the WCP; } \\
\text { - Over half of the respondents reported that they felt 'fitter' and 'active'; } \\
\text { - Qualitative data suggested that they were looking forward to more sport } \\
\text { competitions next year's WCP; }\end{array}$ \\
\hline $\begin{array}{l}\text { Educational Institutions } \\
\text { Their employees normally have } \\
\text { knowledge of the benefits of taking part } \\
\text { in sport and PA, and have comparatively } \\
\text { flexible working hours, with changing and } \\
\text { shower facilities in place; }\end{array}$ & $\begin{array}{ll}\text { - Promotion of WCP by: } \\
-\quad \text { LRS team; } \\
-\quad \text { Emails / newsletter } \\
+\quad \text { Regular visiting of the WCP website (Once or twice a week); } \\
\text { - The effective incentives: } \\
\text { - Sports equipment } \\
\text { - } \quad \text { Tickets to events/matches }\end{array}$ & $\begin{array}{l}\text { - Over half of the respondents reported that their level of participation in } \\
\text { sports and physical activity had increased since taking part in the WCP; } \\
\text { - Over half of the respondents reported that they felt 'fitter', had 'lost } \\
\text { weight', felt 'more healthy and better'; }\end{array}$ \\
\hline $\begin{array}{l}\text { Public Sector/Sport Organisations } \\
\text { Staff in sport organisations had } \\
\text { participated frequently in sports and } \\
\text { physical activity before the WCP (4-5days } \\
\text { a week); } \\
\text { The majority of staff would be interested } \\
\text { in receiving training to help become a } \\
\text { champion for sport and physical activity } \\
\text { at their workplace; }\end{array}$ & $\begin{array}{ll} & \text { Promotion of WCP by: } \\
-\quad \text { LRS team; } \\
-\quad \text { Active Together Partners; } \\
\text { - Emails / newsletter } \\
\text { - Less regular visiting of the WCP website (at least once a } \\
\text { month); } \\
+\quad \text { The effective incentives: } \\
\text { - Money } \\
\text { - Gym membership/sports activities } \\
\text { - Tickets to events/matches } \\
\text { It had been recognised that having a management team } \\
\text { member championing employee's involvement in the WCP } \\
\text { would bring out a better result }\end{array}$ & $\begin{array}{l}\text { - Over half of the respondents reported that they had tried new sports and } \\
\text { physical activity since taking part in the WCP; } \\
\text { - The amount of cycling (from and to work, during lunch-times at work, other } \\
\text { times during the working day, or for leisure purposes) had increased; } \\
\text { - Over half of the respondents reported that WCP fostered social } \\
\text { conversation between work colleagues; } \\
\text { - Qualitative data suggested that they were looking for more sport } \\
\text { competitions in next year's WCP; } \\
\text { - Suggestions for improving the inter workplace competitions include: more } \\
\text { sports; events in the evening, creating local leagues. }\end{array}$ \\
\hline $\begin{array}{l}\text { Private Sector/ Other Participating } \\
\text { Organisations } \\
\text { - The majority had their management team } \\
\text { championing employees' involvement in } \\
\text { WCP; } \\
\text { The majority of staff would be interested } \\
\text { in receiving training to help become a } \\
\text { champion for sport and physical activity } \\
\text { at their workplace; }\end{array}$ & $\begin{array}{ll}\text { - Promotion of WCP by: } \\
\text { - } \quad \text { LRS team; } \\
\text { - Meetings; } \\
\text { - Emails / newsletter } \\
+\quad \text { Often visiting the WCP website (Once or twice a week); } \\
\text { - The effective incentives: } \\
\text { - Vouchers } \\
\text { - } \quad \text { Sports equipment } \\
\text { - Gym membership/sports activities }\end{array}$ & $\begin{array}{l}\text { - Over half of the respondents reported that the level of sports and physical } \\
\text { activity participation had increased since taking part in WCP; } \\
\text { - Over half of the respondents reported that they felt 'fitter', more 'healthy' } \\
\text { and 'active'; } \\
\text { - The major suggestion for improving the inter workplace competitions was } \\
\text { creating local leagues. }\end{array}$ \\
\hline
\end{tabular}




\section{Conclusion}

In this paper we have sought to accomplish a number of goals associated with the questions concerning whether and how increases of participation might be triggered by hosting of mega-sporting events, focussing on the specific occasion of the London Olympic Games. We have concentrated our investigation at the local rather than the national level, because although national statistics on participation can indicate whether participation rates have increased nationally in the period before, during and after the games, such data are not necessarily helpful in contributing to an understanding of the causal mechanisms involved in producing changes in participation rates. In addition the locale on which we focus is a non-hosting region, and little is known about achieving outcomes for such events in regions not directly involved in hosting the mega-event per se.

Our application of the approach in this case allows evaluation of a specific project designed specifically to stimulate participation in the workforce and the workplace. As such it promotes the opportunity to evaluate claims of the causes or generative mechanisms involved in producing outcomes in the specific context of this project, and the various sub-contexts (particularly organisational contexts) in which it had been delivered. The largely implicit assumptions of the logical chain of cause and effect which constitutes the programme theory in this case are able to be subjected to evaluation through quantitative analysis identifying dependent variables which correlate with self-reported increases in participation and through the qualitative data supplied in exploratory interviews with a small number of participants drawn from different types of work organisation.

The goal of realist evaluation is not to answer the question of 'what works?' but to rather to address the mantra of 'What works? For whom? Under what circumstances? And how?'. In our case these questions can be broken down and phrased in the following terms.

- 'Did the staging of the London Games contribute to a greater awareness of the benefits of exercise, and a greater willingness to participate in sport and physical activity?' We have noted that increased awareness of benefits because of the London Games is positively correlated to a self-reported increase in sport and physical activity; to participation in new forms of sport and physical activity; and to greater motivation to participate in sport and physical activity which lends strength to the programme theory, though the correlations are significant but not large. These correlations can be interpreted as lending support to claims of modest levels of project impact.

- 'For which groups was this effect evident?' Here the evidence suggest that the promotion of participation was more effective in some groups than others. Those who were previously inactive manifested the lowest impact. Those who manifest occasional participation were the most likely to increase participation. And those who were the most regular participants before 
participating in the WCP showed a slight increase in participation, which was explained by two of the interviewees as being a product of the lack of free time given the amount of time already dedicated to sport.

- 'In what contexts was the project more likely to be successful?' The identification of varying degrees of commitment associated with different types of organisation is also helpful in identifying particular contexts in which the programme was more readily embedded and the data from qualitative interviews provides useful insights into why this might be the case.

- 'How did the programme work? What were the generative mechanisms in place which fostered successful outcomes?' Here postulated explanations of the mechanisms which brought about the programme outcomes were supported not simply by the statistical associations between processes (e.g. increased awareness) but also outcomes (increased motivation, and reported participation).

In addition to the relationships and outcomes that we sought to illustrate there were a number of unintended consequences also reported by survey respondents in open-ended question responses and by the interviewees. These included reported increases in social interaction and sociability (typically talking about WCP sporting and exercise targets and performance) and a contribution to team cohesion (knowing one's colleagues better). Indeed these would provide interesting avenues to explore in any follow up studies

As we have noted, in undertaking the meta-evaluation of the impact of the Games there was a clear disjunction between on the one hand, the data at national level which indicated no statistically significant growth in participation until the year of the games itself (and such growth as did occur seems to have been short lived) and on the other, the reported successes of many locally delivered schemes in leveraging increased participation. One potential explanation of this conundrum was a failure of many of the local schemes to take into account the question of additionality such that successful attraction of participants reported for local schemes failed to calculate or even estimate leakage, substitution, or displacement and to account for multiplier effects.

We regard the evaluation of a local project in Leicestershire as a contribution to the literature, in part because detailed empirical post hoc evaluation of claims concerning participation impacts of mega-events is rarely undertaken. In addition, while realist evaluation has gained a following in evaluation studies, the application of the approach in relation to sports policy has not been prominent, and where it has been attempted in relation to the analysis of Olympic impact this has tended to adopt an exclusively qualitative approach (see for example, Hughes, 2013) with greater prominence given to analysis of top-down approaches to understanding impact than to local level studies. In this sense we would argue for greater consideration being given to mixed methods local studies framed in a realist evaluation agenda. 


\section{Disclosure statement}

No potential conflict of interest was reported by the authors.

\section{Notes}

1. Although the study presented here was part of a wider review of Olympic impacts commissioned by emda, it was commissioned strictly speaking to cover a sub-region (Leicestershire). For the sake of brevity, we refer throughout to the geographical constituency for the research as 'a non-hosting region'.

2. The 2012 programme participants were asked to indicate their sport and physical activity participation frequency when they registered their profiles at the beginning of the programme, and in the survey collected after the completion of WCP. One group of differences had been captured: 'There was a statistically significant increase in the selfreported level of physical activity participation from Time $1(M=4.62, S D=1.71)$ to Time $2(\mathrm{M}=5.95, \mathrm{SD}=2.18, \mathrm{t}(60)=-5.81, \mathrm{p}=.000$, two-tailed). The mean increase in the selfreported level of physical activity participation was 1.33 days with at least 30 min of MIPA, with a $95 \%$ confidence interval ranging from .87 to 1.79 . The eta squared statistic ( $\eta 2=.36)$ indicates a large effect size'.

3. The three independent samples' t-tests were: (1) variable (i) increase in overall amount of physical activity: males $(M=3.24 ; S D=1.154)$ females $(M=3.26 ; S D=1.052 ; T=-.054$, $\mathrm{p}=.957)$ effect size small (.000039); (2) variable (ii) increase in participation in new sports; males $(\mathrm{M}=2.9 ; \mathrm{SD}=1.175)$ females $(\mathrm{M}=2.87 ; \mathrm{SD}=1.096 ; \mathrm{T}=-.091, \mathrm{p}=.928$ ) effect size small (.000112); (3) variable (iii) increase in participation in sports already practiced; males $(\mathrm{M}=3.14 ; \mathrm{SD}=1.187)$ females $(\mathrm{M}=3.26 ; \mathrm{SD}=1.052 ; \mathrm{T}=-.054, \mathrm{p}=$ .957) effect size small (.002729).

4. There was a significant increase in participation for women from Time $1(M=4.71 ; S D=$ 1.90) to Time $2(M=5.71 ; S D=2.381), t(37)=3.367, p(2$ tailed $)=.002$. The effect size here is large $(\eta 2=.2394)$. However, there was also a significant increase for Males from $\mathrm{T} 1(\mathrm{M}=4.48 ; \mathrm{SD}=1.377)$ to $\mathrm{T} 2(\mathrm{M}=6.35 ; \mathrm{SD}=1.774), \mathrm{t}(22)=5.590, \mathrm{p}(2$ tailed $)=.000$. Again the effect size is large $(\eta 2=.5868)$.

5. The three sets of variables with statistically significant correlations involving variables associated with the London 2012 'effect' were: (1) a moderate, positive correlation between perceived level of agreement with two statements, namely 'the publicity surrounding the 2012 Games made me more aware of the benefits of taking part in sport and physical activity' and 'I have increased [my] overall amount of physical activity' ( $r=$ $.43, n=185, p<.000)$; (2) a small, positive correlation between the level of agreement on the statement 'the publicity surrounding the 2012 Games made me more aware of the benefits of taking part in sport and physical activity' and on the statement, 'I have participated in new sports and leisure activities' ( $r=.21, n=184, p<.005)$; (3) a moderate, positive correlation between the level of agreement on 'the publicity surrounding the 2012 Games made me more aware of the benefits of taking part in sport and physical activity' and on 'The London Games has motivated me to participate in the programme' $[r=.32, n=185, p<.01]$. 


\section{Notes on contributors}

Shushu Chen joined Edge Hill University in 2014, after completing her PhD from Loughborough University. She has a particular interest in sport policy analysis and intervention evaluation, particularly in sport. She is a visiting researcher at the Centre for Olympic Studies and Research, Loughborough University.

Ian Henry is a professor and Director of the Centre for Olympic Studies and Research at Loughborough University, UK. He has published widely in the fields of sport politics, policy analysis and management, and Olympic research, and his work has been commissioned by transnational bodies including the IOC, UNESCO, the Council of Europe and the European Commission, as well as by government departments and sporting bodies in the UK.

\section{References}

Andersen, A. (1999). CREA (1999): Economic impact study of the Sydney 2000 Olympic Games: Sydney and Launceston: Arthur Anderson Consulting \& Centre for Regional Economic Analysis (CREA), University of Tasmania.

Baade, R. A., Baumann, R., \& Matheson, V. A. (2008). Slippery Slope? Assessing the Economic Impact of the 2002 Winter Olympic Games in Salt Lake City, Utah. Région \& Développement, 31, 79-89.

Beesley, L. G., \& Chalip, L. (2011). Seeking (and not seeking) to leverage mega-sport events in non-host destinations: The case of Shanghai and the Beijing Olympics. Journal of Sport \& Tourism, 16(4), 323-344. doi: 10.1080/14775085.2011.635016

Bhaskar, R. (1998). Philosophy and Scientific Realism. In M. Archer, R. Bhaskar, A. Collier, T. Lawson \& A. Norrie (Eds.), Critical Realism: Essential Readings. London: Routledge.

Blake, A. (2005). The Economic Impact of the London 2012 Olympics (N. U. B. S. Christel DeHaan Tourism and Travel Research Institute, Trans.). Nottingham: Nottingham University

Bloyce, D., \& Lovett, E. (2012). Planning for the London 2012 Olympic and Paralympic legacy: a figurational analysis. International Journal of Sport Policy and Politics, 4(3), 361-377.

Bondonio, P., \& Mela, A. (2008). Which legacies of Torino 2006 OWGs for the Olympic movement and the local society? Paper presented at the The Olympic Legacy.

Cashman, R. (2002). Impact of the Games on Olympic host cities. 
Cashman, R. (2006). The Bitter Sweet Awakening: The Legacy of the Sydney 2006 Olympic Games. Olympika :the international journal of Olympic studies.

Chen, S. (2013). An evaluation of the sub-regional legacy/ impacts of the London 2012 Olympic Games in a non-hosting sub-region: a case study of Leicestershire. (Doctoral), Loughborough University Loughborough.

Chen, S., Henry, I., \& Ko, L.-M. (2013). Meta-evaluation, analytic logic models and the assessment of impacts of sports policies. In I. Henry \& L.-M. Ko (Eds.), Handbook of Sport Policy. London: Routledge.

Craig, C. L., \& Bauman, A. E. (2014). The impact of the Vancouver Winter Olympics on population level physical activity and sport participation among Canadian children and adolescents: population based study. International Journal of Behavioral Nutrition and Physical Activity, 11. doi: 10.1186/s12966-014-0107y

Crompton, J. (1995). Economic impact analysis of sports facilities and Events, eleven sources of Misapplication (Analyse des impacts economiques des evenements et equipements sportifs, 11 sources de malentendus). Journal of Sport Management, 9(1), 14-35.

Dansero, E., \& Puttilli, M. (2010). Mega-events tourism legacies: the case of the Torino 2006 Winter Olympic Games - a territorialisation approach. Leisure Studies, 29(3), 321-341. doi: 10.1080/02614361003716966

DCMS. (2010). Free Swimming Programme: Throughput data by local authority: Statistical release - May 2010. London: Department of Culture Media and Sport.

Deccio, C., \& Baloglu, S. (2002). Nonhost community resident reactions to the 2002 Winter Olympics: the spillover impacts. Journal of Travel Research, 41(1), 4656. doi: $10.1177 / 0047287502041001006$

Feng, J., \& Hong, F. (2013). The Legacy: Did the Beijing Olympic Games have a LongTerm Impact on Grassroots Sport Participation in Chinese Townships? International Journal of the History of Sport, 30(4), 407-421. doi: 10.1080/09523367.2013.765725

Fourie, J., \& Santana-Gallego, M. (2011). The impact of mega-sport events on tourist arrivals. Tourism Management, In Press, Corrected Proof. doi: 10.1016/j.tourman.2011.01.011

Giannoulakis, C., Wang, C., \& Gray, D. (2008). Measuring volunteer motivation in mega-sporting events. Event Management, 11(4), 191-200. doi: $10.3727 / 152599508785899884$ 
Gibson, H. J., Qi, X., \& Zhang, J. J. (2008). Destination Image and Intent to Visit China and the 2008 Beijing Olympic Games. Journal of Sport Management, 22(4), 427-450.

Gibson, O. (2011, 1 March). Jeremy Hunt admits London 2012 legacy targets will be scrapped. T, 29 March, p. 1. , The Guardian [online]

Giesecke, J., \& Madden, J. R. (2007). The Sydney Olympics, seven years on: an ex-post dynamic CGE assessment: Monash University, Centre of Policy Studies and the Impact Project.

Gilmore, A. (2014). Evaluating legacies: Research, evidence and the regional impact of the Cultural Olympiad. Cultural Trends, 23(1), 29-41. doi: 10.1080/09548963.2014.862001

Gold, J. R., \& Gold, M. M. (2009). Riding the Mexican Wave? Deciphering the meaning of Olympic Legacy. The Olympic Legacy, 9.

Grant Thornton, Ecorys, \& Centre for Olympic Studies \& Research Loughborough University. (2011). Report 1: Scope, research questions and strategy MetaEvaluation of the Impacts and Legacy of the London 2012 Olympic Games and Paralympic Games. London: Department of Culture Media and Sport.

Grant Thornton, Ecorys, Centre for Olympic Studies \& Research Loughborough University, \& Oxford Economics. (2011). Report 2: Methods Meta-Evaluation of the Impacts and Legacy of the London 2012 Olympic Games and Paralympic Games (Vol. Report 3). London: Department of Culture, Media and Sport.

Grant Thornton, Ecorys, Centre for Olympic Studies \& Research Loughborough University, \& Oxford Economics. (2012a). Report 3: baseline and counterfactual Meta-Evaluation of the Impacts and Legacy of the London 2012 Olympic Games and Paralympic Games (Vol. Report 3). London: Department of Culture, Media and Sport.

Grant Thornton, Ecorys, Centre for Olympic Studies \& Research Loughborough University, \& Oxford Economics. (2012b). Report 4: interim evaluation MetaEvaluation of the Impacts and Legacy of the London 2012 Olympic Games and Paralympic Games (Vol. Report 3). London: Department of Culture, Media and Sport.

Grant Thornton, ECORYS, Centre for Olympic Studies \& Research Loughborough University, \& Oxford Economics. (2013a). Metaevaluation Sport Evidence Base. Unpublished.

Grant Thornton, Ecorys, Centre for Olympic Studies \& Research Loughborough University, \& Oxford Economics. (2013b). Report 5: Post Games evaluation Meta-Evaluation of the Impacts and Legacy of the London 2012 Olympic 
Games and Paralympic Games (Vol. Report 3). London: Department of Culture, Media and Sport.

Gratton, C., \& Jones, I. (2004). Research methods for sport studies. London: Routledge.

Gratton, C., \& Preuss, H. (2008). Maximizing Olympic Impacts by Building Up Legacies. The International Journal of the History of Sport, 25(14), 1922-1938. doi: $10.1080 / 09523360802439023$

Guala, A., \& Turco, D. M. (2009). Resident perceptions of the 2006 Torino Olympic Games, 2002-2007. Choregia: Sport Management International Journal, 5(2), 21-42.

Haynes, J. (2001). Socio-economic impact of the Sydney 2000 Olympic Games. Barcdelona: CEO-UAB.

Heuvel, A. V. (2001). The impact of the Olympics on participation in Australia: trickle down effect, discouragement effect or no effect: National Centre for Culture and Recreation Statistics.

Horne, J. (2007). The Four 'Knowns' of Sports Mega-Events. Leisure Studies, 26(1), 81.

Hughes, K. (2013). Sport Mega-Events and a Legacy of Increased Sport Participation: An Olympic Promise Or An Olympic Dream? (PhD), Leeds Metropolitan University.

Inspire Leicestershire. (2009). Inspire Leicestershire: Leicestershire Strategy for the 2012 Games.

Jinxia, D., \& Mangan, J. A. (2008). Beijing Olympics Legacies: Certain Intentions and Certain and Uncertain Outcomes. The International Journal of the History of Sport, 25(14), 2019-2040. doi: 10.1080/09523360802439031

Jones, H., Millward, P., \& Buraimo, B. (2011). Adult participation in sport: Analysis of the Taking Part Survey. London: Depatment of Cutlture Media and Sport.

Kapareliotis, I., Panopoulos, A., \& Panigyrakis, G. (2010). The influence of the Olympic Games on Beijing consumers' perceptions of their city tourism development. Asia Pacific Journal of Marketing and Logistics, 22(1), 90-100.

Kaplanidou, K., \& Karadakis, K. (2010). Understanding the Legacies of a Host Olympic City: The Case of the 2010 Vancouver Olympic Games. Sport Marketing Quarterly, 19(2), 110-117.

Karadakis, K., \& Kaplanidou, K. (2012). Legacy perceptions among host and non-host Olympic Games residents: a longitudinal study of the 2010 Vancouver Olympic Games. European Sport Management Quarterly, 12(3), 243-264. doi: 10.1080/16184742.2012.680067 
Kavetsos, G., \& Szymanski, S. (2010). National well-being and international sports events. Journal of Economic Psychology, 31(2), 158-171. doi: 10.1016/j.joep.2009.11.005

Kellett, P., Hede, A.-M., \& Chalip, L. (2008). Social Policy for Sport Events: Leveraging (Relationships with) Teams from other Nations for Community Benefit. European Sport Management Quarterly, 8(2), 101-121. doi: $10.1080 / 16184740802024344$

Kim, S. S., \& Petrick, J. F. (2005). Residents' perceptions on impacts of the FIFA 2002 World Cup: the case of Seoul as a host city. Tourism Management, 26(1), 2538. doi: 10.1016/j.tourman.2003.09.013

Kirkup, N., \& Major, B. (2006). Doctoral Foundation Paper: The Reliability of Economic Impact Studies of the Olympic Games: A Post-Games Study of Sydney 2000 and Considerations for London 2012. Journal of Sport \& Tourism, 11(3/4), 275-296.

Lenskyj, H. (2000). Inside the Olympic industry : power, politics, and activism. Albany ; [Great Britain]: State University of New York Press.

Lenskyj, H. (2002). The best Olympics ever? : social impacts of Sydney 2000. Albany ; [Great Britain]: State University of New York Press.

Lenskyj, H. (2008). Olympic industry resistance : challenging Olympic power and propaganda. Albany: State University of New York Press.

Mahtani, K. R., Protheroe, J., Slight, S. P., Demarzo, M. M. P., Blakeman, T., Barton, C. A., . . . Roberts, N. (2013). Can the London 2012 Olympics 'inspire a generation' to do more physical or sporting activities? An overview of systematic reviews. BMJ open, 3(1). doi: 10.1136/bmjopen-2012-002058

Malfas, M., Theodoraki, E., \& Houlihan, B. (2004). Impacts of the Olympic Games as mega-events. Proceedings of the institution of civil engineers, ME3.

Mangan, J. A. (2008). Prologue: Guarantees of Global Goodwill: Post-Olympic Legacies - Too Many Limping White Elephants? International Journal of the History of Sport, 25(14), 1869.

McCartney, G., Thomas, S., Thomson, H., Scott, J., Hamilton, V., Hanlon, P., . . Bond, L. (2010). The health and socioeconomic impacts of major multi-sport events: systematic review (1978-2008). BMJ, 340(c2369), (20 May 2010).

Moreira, P. (2009). A mega-event inside the Great Wall of China: Expectations and possible impacts of the Beijing 2008 Olympic Games. The Olympic Legacy, 45.

Murphy, N. M., \& Bauman, A. (2007). Mass sporting and physical activity events: are they bread and circuses or public health interventions to increase population levels of physical activity? Journal of Physical Activity and Health, 4, 193-202. 
Newman, H. K. (1999). Neighborhood impacts of Atlanta's Olympic Games. Community Development Journal, 34(2), 151-159.

Pawson, R. (2001). Evidence based policy : 1. in search of a method: ESRC UK Centre for Evidence Based Policy and Practice.

Pawson, R. (2006). Evidence-based policy: a realist perspective. London: Sage.

Pawson, R. (2013). The science of evaluation : a realist manifesto. London: SAGE.

Pawson, R., \& Tilley, N. (1997). Realistic Evaluation: Sage Publications (CA).

Pawson, R., \& Tilley, N. (2004). Realist Evaluation. Evaluation, 48, 1-36.

Piper, H., \& Garratt, D. (2013). Olympic Dreams and Social Realities: Foucauldian Analysis of Legacy and Mass Participation. Sociological research online, 18(2). doi: $10.5153 /$ sro.3063

Porter, P. K., \& Fletcher, D. (2008). The economic impact of the Olympic Games: Ex ante predictions and ex poste reality. Journal of Sport Management, 22(4), 470-486.

PricewaterhouseCoopers. (2010). Evaluation of the impact of Free Swimming. London: PricewaterhouseCoopers.

PriceWaterhouseCoopers, \& DCMS. (2005). Olympic Games Impact Study-Final report. Retrieved June 2011, from http://www.gamesmonitor.org.uk/files/PWC\%20OlympicGamesImpactStudy. pdf

Putsis, W. P. (1998). Winners and losers: Redistribution and the use of economic impact analysis in marketing. Journal of Macromarketing, 18(1), 24-33.

Reis, A. C., de Sousa-Mast, F. R., \& Gurgel, L. A. (2014). Rio 2016 and the sport participation legacies. Leisure Studies, 33(5), 437-453. doi: 10.1080/02614367.2012.758304

Ritchie, B. W., Shipway, R., \& Cleeve, B. (2009). Resident Perceptions of MegaSporting Events: A Non-Host City Perspective of the 2012 London Olympic Games. Journal of Sport \& Tourism, 14(2/3), 143-167.

Spilling, O. R. (1996). Mega-event as strategy for regional development: The case of the 1994- Lillehammer Winter Olympics. Entrepreneurship and Regional Development, 8(4), 321-343.

Sport England. (2011). Active People. Retrieved 12 October 2012, 2012, from http://www.sportengland.org/research/active_people_survey.aspx

Tew, G. A., Copeland, R. J., \& Till, S. H. (2012). Sport and exercise medicine and the Olympic health legacy. Bmc Medicine, 10. doi: 10.1186/1741-7015-10-74 
Tien, C., Lo, H., \& Lin, H. (2011). The Economic Benefits of Mega Events: A Myth or a Reality? A Longitudinal Study on the Olympic Games. Journal of Sport Management, 25(1), 11-23.

Toohey, K. (2008). The Sydney Olympics: Striving for Legacies - Overcoming ShortTerm Disappointments and Long-Term Deficiencies. International Journal of the History of Sport, 25(14), 1953.

Truno, E. (1995). Barcelona: City of sport in The Keys to success: the social, sporting, economic and communications impact of Barcelona'92. In M. d. Moragas \& M. Botella (Eds.).

Veal, A., \& Toohey, K. (2005). Sport for All \& the legacy of Sydney 2000 Olympic Games. Paper presented at the the Third International Event Management Research Conference, Sydney.

Walton, H., Longo, A., \& Dawson, P. (2008). A contingent valuation of the 2012 London Olympic games - A regional perspective. Journal of Sports Economics, 9(3), 304-317. doi: 10.1177/152002507308769

Weed, M., Coren, E., Fiore, J., Chatziefstathiou, D., Mansfield, L., \& Wellard, I. (2008). A systematic review of the evidence base for developing a physical activity, sport and health legacy from the London 2012 Olympic and Paralympic Games. Canterbury: Centre for Sport, Physical Education \& Activity Research (SPEAR), Canterbury Christ Church University.

Weinstein, N. (1988). The precaution adoption process. Health Psychol, 7, 355 - 386.

Zhou, Y., \& Ap, J. (2009). Residents' Perceptions towards the Impacts of the Beijing 2008 Olympic Games. Journal of Travel Research, 48(1), 78-91. 
Table 2: Summary of the chain of logic constituting the WCP 'programme theory'

1. The publicity accorded to the staging of the Olympics in the UK provides a focus for publicity concerning sport.

2. The affective impact (for many people) of the prospect of the proximity of this megaevent generates greater interest in, and a positive response to, sport-related lifestyles for a significant proportion of the population.

3. The Leicestershire Steering Group / Inspire Leicestershire provided information on the benefits of exercise, the required levels of participation and intensity required to generate health benefits, as well as information on how participation in sport and activity in the workplace, or among the workforce, can be increased.

4. The incentive to participate in sport and physical activity will be strengthened, and tendencies for recidivism will be undermined, if records of progress are kept and performance, in terms of maintaining increased levels of participation, rewarded.

5. The provision of opportunities for sport (in intra- and inter-organisational competitions) will provide opportunities for social contexts (e.g. teamwork promoting social bonding), which have the potential to make exercise and the context of exercise more enjoyable.

6. Competition between organisations in terms of levels of exercise undertaken by the workforce, and measurement and recording of exercise levels, will motivate employees to sustain and improve their performance.

7. The increase in physical activity that is thus promoted will enhance the physical health of those members of the workforce who participate, and thus will reduce public health costs. 
Table 2 Defining the four key additionality related concepts in the case of WCP

\begin{tabular}{|c|c|c|}
\hline Concepts & WCP & Finding \\
\hline Leakage & $\begin{array}{l}\text { i) Since the WCP was aimed at ensuring Leicestershire residents } \\
\text { were more active, beneficiaries of the WCP who live outside of } \\
\text { Leicestershire and benefit from the programme would constitute } \\
\text { leakage. } \\
\text { (ii) Since the programme was intended to target 'less active' adults } \\
\text { in the workplace to become active, there is a possibility that in fact a } \\
\text { large number of 'active' adults benefited from the programme, } \\
\text { constituting a second form of 'leakage. }\end{array}$ & $\begin{array}{l}\text { i) The first form of leakage proved to be negligible. WCP demographics indicated that } \\
\text { majority of participants reside in Leicestershire. } \\
\text { (ii) There was a leakage in the programme in the sense that, as identified in the interviews, } \\
\text { majority impact was reported by a group of people who were already active and were not } \\
\text { therefore the intended target (or at least not the primary intended target) of the } \\
\text { intervention. }\end{array}$ \\
\hline Displacement & $\begin{array}{l}\text { Refers to the case which the WCP displaces existing programme(s) } \\
\text { of sport or physical activity provided for example by the employer. }\end{array}$ & $\begin{array}{l}\text { Interestingly, it was evident from the qualitative data that some of the workplaces were } \\
\text { designing a similar initiative within their organisations, or had already been running their own } \\
\text { workplace challenge programme. While WCP was taking place, they either linked the two } \\
\text { programmes together or stopped their own programme and took part in WCP (the latter } \\
\text { action constituting a form of displacement). Where such displacement took place qualitative } \\
\text { interviews indicated that this was largely because WCP was perceived as better organised, } \\
\text { and initiatives. Such as the mini-leagues between different organisations were regarded as } \\
\text { more enjoyable. In this respect, displacement did exist and this is a cost which, though not } \\
\text { quantified, nevertheless should be borne in mind when summarising the final impacts of the } \\
\text { programme. }\end{array}$ \\
\hline Substitution & $\begin{array}{l}\text { Refers to the situation in which, as a consequence of taking part in } \\
\text { the sporting or physical activity competitions provided by WCP, } \\
\text { participants ceased to participate in other sporting or fitness } \\
\text { activities. In such cases they would have substituted WCP activities } \\
\text { for others. }\end{array}$ & $\begin{array}{l}\text { The questionnaire asked respondents to specify whether they had experienced a net increase } \\
\text { in participation, in other words such a measure would allow for overall participation data to } \\
\text { be calculated while making allowance for forms of substitution. }\end{array}$ \\
\hline Multiplier effects & $\begin{array}{l}\text { Refers to, for example, after recognising and experiencing those } \\
\text { physical related or mental related benefits as a result of regularly } \\
\text { taking part in sport and physical activity via WCP, the participants } \\
\text { may start to encourage their friends and family to join the scheme } \\
\text { or doing exercise on their own. }\end{array}$ & The multiplier effect was not captured in this case. \\
\hline
\end{tabular}


Table $3 \mathrm{CMO}_{1}$ for the WCP in terms of different intensity level of sports and physical activities participation

\begin{tabular}{|c|c|c|c|c|}
\hline \multicolumn{2}{|c|}{ Contexts } & \multirow{2}{*}{ Mechanisms } & \multicolumn{2}{|c|}{ Outcomes } \\
\hline Conjectured & Observed & & Conjectured & Observed \\
\hline $\begin{array}{l}\text { - The majority work as office - } \\
\text { based employees } \\
\text { - Inspired by the context of } \\
\text { publicity in relation to the London } \\
\text { Games }\end{array}$ & $\begin{array}{l}\text { - Lack of awareness of the } \\
\text { recommended physical } \\
\text { activity level for adults } \\
\text { The publicity surrounding the } \\
\text { London Games made them } \\
\text { more aware of the benefits of } \\
\text { taking part in sport and } \\
\text { physical activity } \\
\text { Potential constraints - a lack } \\
\text { of shower post exercise }\end{array}$ & $\begin{array}{l}\text { - Promotional materials in order to increase } \\
\text { the awareness of WCP and the benefits of } \\
\text { participating in sport and physical activity } \\
\text { - Starting to log their activities on website } \\
\text { heightens awareness; } \\
+\quad \text { Participation in the Cycle/Active Travel } \\
\text { Challenge } \\
\text { The effective incentives }{ }^{6} \text { : Sports Shop } \\
\text { Vouchers }\end{array}$ & \multirow{5}{*}{$\begin{array}{l}\text { - Healthy lifestyles leading to } \\
\text { other psychological benefits, } \\
\text { such as happiness, confidence; } \\
=\quad \text { Improved social networking in } \\
\text { the workplace; }\end{array}$} & $\begin{array}{l}\text { - Moving towards more } \\
\text { regular participation in sport } \\
\text { and physical activity } \\
\text { - An increase in self } \\
\text { confidence in the workplace }\end{array}$ \\
\hline \multicolumn{2}{|c|}{$\begin{array}{l}\text { People who have participated in sport and physical activity but relatively } \\
\text { less often (1-3 days a week) prior to the staging of the WCP }\end{array}$} & & & \\
\hline $\begin{array}{l}\text { Be aware of the benefits of } \\
\text { participation in sport } \\
\text { - Have some interests in sport and } \\
\text { physical activity }\end{array}$ & $\begin{array}{l}\text { - } \quad \text { Reported time barriers } \\
\text { - } \\
\text { spormally preferred doing physical activity on } \\
\text { their own } \\
\text { - Potential constraint - a lack of } \\
\text { shower facilities at work }\end{array}$ & $\begin{array}{l}\text { - The Log Section motivated them to } \\
\text { participate more in sport and physical } \\
\text { activity; } \\
\text { Participated in the Cycle/Active Travel } \\
\text { Challenge }\end{array}$ & & $\begin{array}{l}\text { - An increase in sport and } \\
\text { physical activity } \\
\text { participation } \\
\text { - Achieved a sense of } \\
\text { achievement }\end{array}$ \\
\hline \multicolumn{2}{|c|}{$\begin{array}{c}\text { People who have regularly participated in sport and physical activity (more } \\
\text { than } 4 \text { days a week) prior to the staging of the WCP }\end{array}$} & & & \\
\hline $\begin{array}{l}\text { For those involved in sport their } \\
\text { sport-related job roles heavily } \\
\text { influence decisions to participate } \\
\text { in sport } \\
\text { - } \quad \text { Strong interests in sport and } \\
\text { physical activity } \\
\text { - Higher level of awareness of the } \\
\text { benefits of participation in sport }\end{array}$ & $\begin{array}{l}\text { Lack of additional free time } \\
\text { for undertaking more sport } \\
\text { and physical activity } \\
\text { - Length of } 2011 \text { WCP - too long }\end{array}$ & $\begin{array}{l}\text { - } \quad \text { Engaged in different sporting competitions } \\
\text { - Joined the mini-leagues }\end{array}$ & & $\begin{array}{l}\text { - } \quad \text { Had a chance to try new and } \\
\text { different sport and physical } \\
\text { activity } \\
\text { - } \quad \text { Kept them sustain } \\
\text { - } \quad \text { Met more colleagues } \\
\text { - Increased social } \\
\text { conversation }\end{array}$ \\
\hline
\end{tabular}




\begin{tabular}{|c|c|c|c|}
\hline Contexts & & Mechanisms & Outcomes \\
\hline $\begin{array}{l}\text { Local Authorities } \\
\text { - Worked closely with LRS on a daily basis; }\end{array}$ & & $\begin{array}{l}\text { Promoting WCP by the following three main communication } \\
\text { channels: } \\
\text { - } \quad \text { LRS team; } \\
\text { - } \quad \text { Active Together Partners; } \\
\text { - Emails / newsletter } \\
\text { - Regular visiting of the WCP website (Once or twice a week); } \\
\text { - The effective incentives: } \\
\text { - Sports shop vouchers } \\
\text { - } \quad \text { Tickets to events/matches } \\
\text { - Sports equipment } \\
\text { Strong management support by own organisation was viewed } \\
\text { as critical }\end{array}$ & $\begin{array}{l}\text { - Over half of the respondents reported that the level of sports and physical } \\
\text { activity participation had increased since taking part in the WCP; } \\
\text { - Over half of the respondents reported that they felt 'fitter' and 'active'; } \\
\text { - Qualitative data suggested that they were looking forward to more sport } \\
\text { competitions next year's WCP; }\end{array}$ \\
\hline $\begin{array}{l}\text { Educational Institutions } \\
\text { Their employees normally have } \\
\text { knowledge of the benefits of taking part } \\
\text { in sport and PA, and have comparatively } \\
\text { flexible working hours, with changing and } \\
\text { shower facilities in place; }\end{array}$ & + & $\begin{array}{l}\text { - Promotion of WCP by: } \\
\text { - } \quad \text { LRS team; } \\
\text { - } \quad \text { Emails / newsletter } \\
\text { - } \quad \text { The effective incentives: } \\
\text { - } \quad \text { Sports equipment } \\
\text { - } \quad \text { Tickets to events/matches }\end{array}$ & $\begin{array}{l}\text { - Over half of the respondents reported that their level of participation in } \\
\text { sports and physical activity had increased since taking part in the WCP; } \\
\text { - Over half of the respondents reported that they felt 'fitter', had 'lost } \\
\text { weight', felt 'more healthy and better'; }\end{array}$ \\
\hline $\begin{array}{l}\text { Public Sector/Sport Organisations } \\
\text { - Staff in sport organisations had } \\
\text { participated frequently in sports and } \\
\text { physical activity before the WCP (4-5days } \\
\text { a week); } \\
\text { The majority of staff would be interested } \\
\text { in receiving training to help become a } \\
\text { champion for sport and physical activity } \\
\text { at their workplace; }\end{array}$ & + & $\begin{array}{l}\text { - Promotion of WCP by: } \\
\text { - } \quad \text { LRS team; } \\
\text { - } \quad \text { Active Together Partners; } \\
\text { - } \quad \text { Emails / newsletter } \\
\text { Less regular visiting of the WCP website (at least once a } \\
\text { month); } \\
\text { - The effective incentives: } \\
\text { - Money } \\
\text { - Gym membership/sports activities } \\
\text { - Tickets to events/matches } \\
\text { It had been recognised that having a management team } \\
\text { member championing employee's involvement in the WCP } \\
\text { would bring out a better result }\end{array}$ & $\begin{array}{l}\text { - Over half of the respondents reported that they had tried new sports and } \\
\text { physical activity since taking part in the WCP; } \\
\text { - The amount of cycling (from and to work, during lunch-times at work, other } \\
\text { times during the working day, or for leisure purposes) had increased; } \\
\text { - Over half of the respondents reported that WCP fostered social } \\
\text { conversation between work colleagues; } \\
\text { - Qualitative data suggested that they were looking for more sport } \\
\text { competitions in next year's WCP; } \\
\text { - Suggestions for improving the inter workplace competitions include: more } \\
\text { sports; events in the evening, creating local leagues. }\end{array}$ \\
\hline $\begin{array}{l}\text { Private Sector/ Other Participating } \\
\text { Organisations } \\
\text { - The majority had their management team } \\
\text { championing employees' involvement in } \\
\text { WCP; } \\
\text { The majority of staff would be interested } \\
\text { in receiving training to help become a } \\
\text { champion for sport and physical activity }\end{array}$ & + & $\begin{array}{l}\text { Promotion of WCP by: } \\
\text { - } \quad \text { LRS team; } \\
\text { - Meetings; } \\
\text { - } \quad \text { Emails / newsletter } \\
\text { - Often visiting the WCP website (Once or twice a week); } \\
\text { - The effective incentives: } \\
\text { - Vouchers } \\
\text { - } \quad \text { Sports equipment }\end{array}$ & $\begin{array}{l}\text { - Over half of the respondents reported that the level of sports and physical } \\
\text { activity participation had increased since taking part in WCP; } \\
\text { - Over half of the respondents reported that they felt 'fitter', more 'healthy' } \\
\text { and 'active'; } \\
\text { - The major suggestion for improving the inter workplace competitions was } \\
\text { creating local leagues. }\end{array}$ \\
\hline
\end{tabular}


Figure 1: The Context of the Regional Strategy for Leveraging Benefits from the London 2012 Olympic and Paralympic Games in Leicestershire.

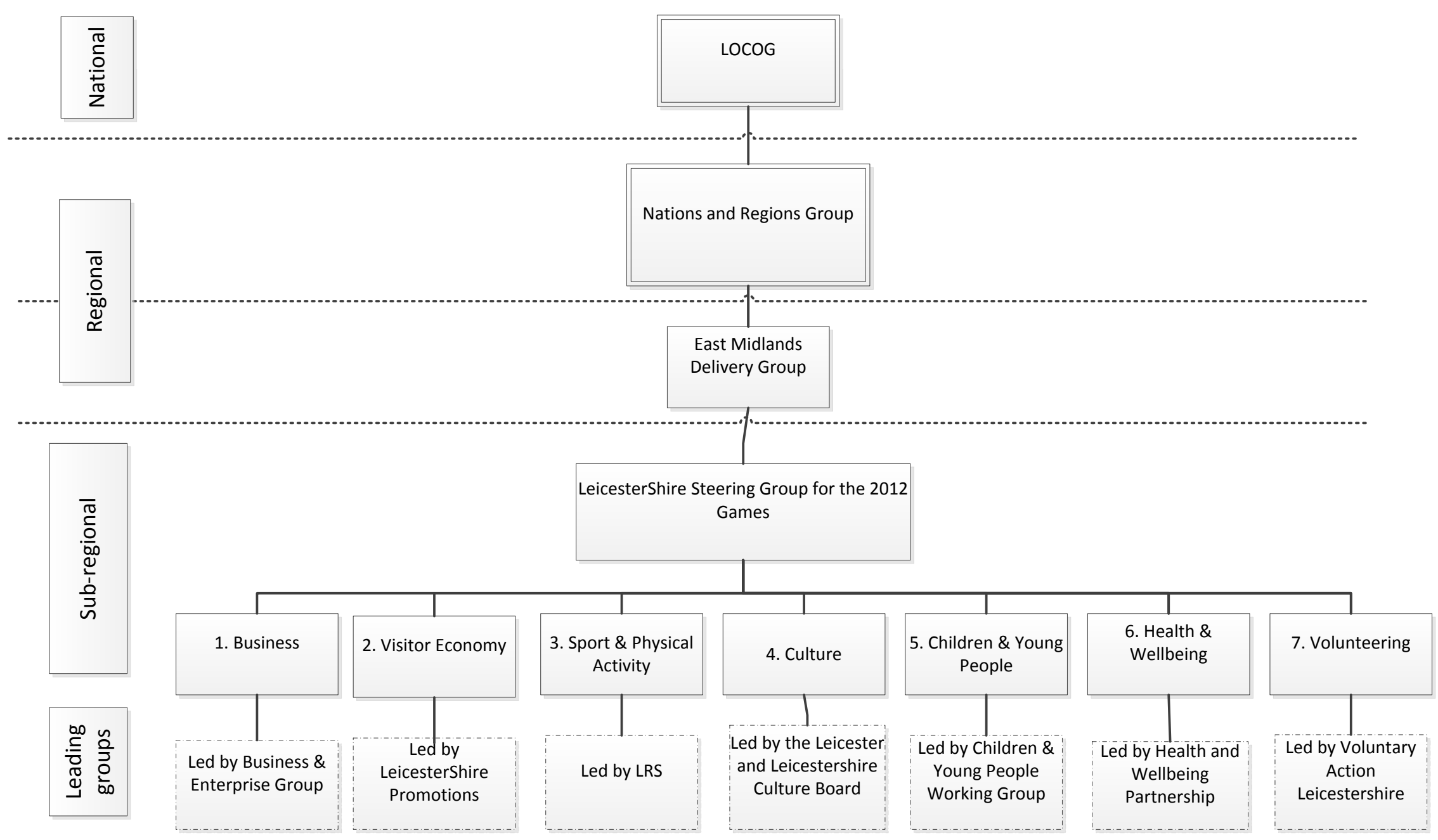


Figure 2 Comparison of the days of moderate intensity physical activity (at least 30 minutes) per week before and after the 2012 Challenge programme

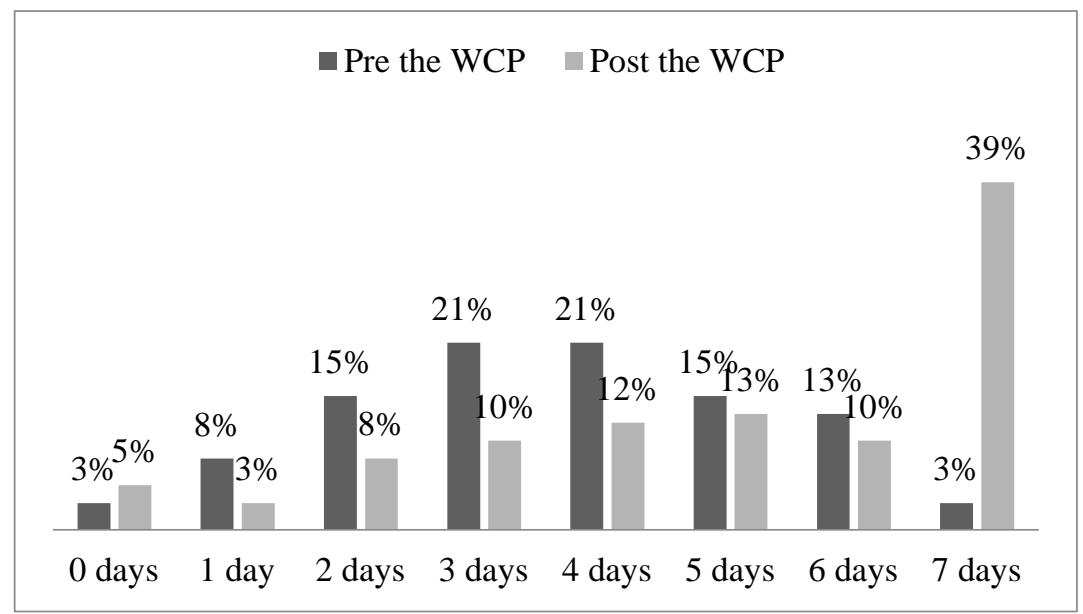




\section{Endnotes}

${ }^{1}$ Although the study presented here was part of a wider review of Olympic impacts commissioned by emda, it was commissioned strictly speaking to cover a sub-region (Leicestershire). For the sake of brevity we refer throughout to the geographical constituency for the research as 'a non-hosting region'.

${ }^{2}$ The 2012 programme participants were asked to indicate their sport and physical activity participation frequency when they registered their profiles at the beginning of the programme, and in the survey collected after the completion of WCP. One group of differences had been captured:

- There was a statistically significant increase in the self-reported level of physical activity participation from Time $1\left(M=4.62^{1}, S D=1.71\right)$ to Time 2 ( $M$ $=5.95, \mathrm{SD}=2.18, \mathrm{t}(60)=-5.81, \mathrm{p}=.000$, two-tailed $)^{1}$. The mean increase in the self-reported level of physical activity participation was 1.33 days with at least 30 minutes of moderate intensity physical activity (MIPA), with a 95\% confidence interval ranging from .87 to 1.79 . The eta squared statistic (Eta squared $=.36$ ) indicates a large effect size.

${ }^{3}$ The three independent samples t-tests were:

- Variable (i) Increase in overall amount of physical activity: Males (M=3.24;SD $=1.154)$ Females $(M=3.26 ; S D=1.052 ; T=-.054, p=.957)$ effect size small (.000039);

- Variable (ii) Increase in participation in new sports; Males ( $M=2.9 ; \mathrm{SD}=1.175)$ Females ( $M=2.87 ; \mathrm{SD}=1.096 ; \mathrm{T}=-.091, \mathrm{p}=.928)$ effect size small (.000112);

- Variable (iii) Increase in participation in sports already practiced; Males $(M=3.14 ; S D=1.187)$ Females $(M=3.26 ; S D=1.052 ; T=-.054, p=.957)$ effect size small (.002729).

${ }^{4}$ There was a significant increase in participation for women from Time $1(M=4.71$; $\mathrm{SD}=1.90)$, to Time $2(\mathrm{M}=5.71 ; \mathrm{SD}=2.381), \mathrm{t}(37)=3.367, \mathrm{p}$ ( 2 tailed $)=.002$. The effect size here is large (eta squared $=.2394$ ). However there was also a significant increase for Males from T1 ( $M=4.48 ; S D=1.377)$ to $T 2(M=6.35 ; S D=1.774), t(22)=5.590, p(2$ tailed) $=.000$. Again the effect size is large (eta squared $=.5868$ ).

${ }^{5}$ The three sets of variables with statistically significant correlations involving variables associated with the London 2012 'effect' were:

- A moderate, positive correlation between perceived level of agreement with two statements, namely 'the publicity surrounding the 2012 Games made me more aware of the benefits of taking part in sport and physical activity' and 'I have increased [my] overall amount of physical activity' $[r=.43, n=185, p$ $<.000]$;

- A small, positive correlation between the level of agreement on the statement 'the publicity surrounding the 2012 Games made me more aware of the benefits of taking part in sport and physical activity' and on the 
statement, 'I have participated in new sports and leisure activities' $[r=.21, n$ $=184, \mathrm{p}<.005$.

${ }^{6}$ There were six types of prize/incentive cited from which the survey respondents were asked to select those which may encourage their participation in a future WCP. They were: Money, Sports equipment, Training, Tickets to events/matches, Gym membership/sport activities, and Sports Shop Vouchers. 